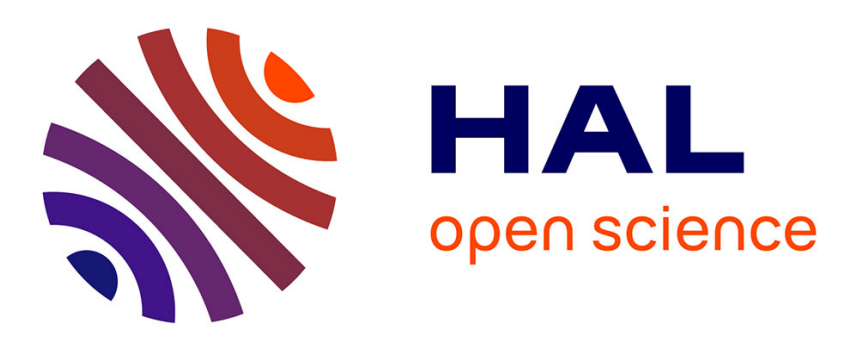

\title{
Climate change: The 2015 Paris Agreement thresholds and Mediterranean basin ecosystems
}

\author{
Joel Guiot, Wolfgang Cramer
}

\section{To cite this version:}

Joel Guiot, Wolfgang Cramer. Climate change: The 2015 Paris Agreement thresholds and Mediterranean basin ecosystems. Science, 2016, 354 (6311), pp.465-468. 10.1126/science.aah5015 . hal01586010

\section{HAL Id: hal-01586010 https://hal.science/hal-01586010}

Submitted on 12 Sep 2017

HAL is a multi-disciplinary open access archive for the deposit and dissemination of scientific research documents, whether they are published or not. The documents may come from teaching and research institutions in France or abroad, or from public or private research centers.
L'archive ouverte pluridisciplinaire HAL, est destinée au dépôt et à la diffusion de documents scientifiques de niveau recherche, publiés ou non, émanant des établissements d'enseignement et de recherche français ou étrangers, des laboratoires publics ou privés. 
26. L. Overstreet Wadiche, D. A. Bromberg, A. L. Bensen, G. L. Westbrook, J. Neurophysiol. 94, 4528-4532 (2005)

27. S. Ge et al., Nature 439, 589-593 (2006).

28. S. Heigele, S. Sultan, N. Toni, J. Bischofberger, Nat. Neurosci. 19. 263-270 (2016)

29. C. Vivar et al., Nat. Commun. 3, 1107 (2012).

30. L. Madisen et al., Nat. Neurosci. 15, 793-802 (2012).

31. L. Acsády, A. Kamondi, A. Sík, T. Freund, G. Buzsáki, J. Neurosci. 18, 3386-3403 (1998)

32. C. J. Magnus et al., Science 333, 1292-1296 (2011).

33. T. J. Stachniak, A. Ghosh, S. M. Sternson, Neuron 82, 797-808 (2014).

34. S. Ge, C. H. Yang, K. S. Hsu, G. L. Ming, H. Song, Neuron 54 , 559-566 (2007)

35. A. Marín-Burgin, L. A. Mongiat, M. B. Pardi, A. F. Schinder, Science 335, 1238-1242 (2012).
36. A. Tashiro, V. M. Sandler, N. Toni, C. Zhao, F. H. Gage, Nature 442, 929-933 (2006)

37. D. Dupret et al., PLOS Biol. 5, e214 (2007).

\section{ACKNOWLEDGMENTS}

We thank S. Arber and M. Soledad Espósito for providing AAV-hM4Di and AAV-PSAM-5HT3 particles and for invaluable advice on their use, M. C. Monzón Salinas for technical help, S. Sternson for PSEM ${ }^{308}$, B. Roth for the hM3Dq and hM4Di constructs, G. Davies Sala for preliminary experiments using retroviral expression of hM3Dq. J. Johnson for Ascl1 ${ }^{\text {CreERT2 }}$ mice, S. Arber for PVCre mice, members of the A.F.S. and G. Lanuza labs for insightful discussions, and V. Piatti for critical comments on the manuscript. D.G. and A.F.S. are investigators of the Consejo Nacional de Investigaciones Científicas y Técnicas (CONICET). Supported CONICET fellowships (D.D.A., S.M.Y., M.F.T., and S.G.T.), Howard Hughes Medical Institute SIRS grant 55007652 (A.F.S.), Argentine Agency for the Promotion of Science and Technology grant PICT2013-1685, and NIH grant FIRCA
R03TW008607-01. The data reported in this manuscript are tabulated in the main paper and the supplementary materials. Author contributions: D.D.A. and D.G. contributed to the concept, designed and performed the experiments, analyzed the data, and wrote the manuscript; S.M.Y. and S.G.T. performed electrophysiological recordings and analyzed the data; M.F.T. and K.A.B. contributed to experiments involving enriched environment and analyzed the data; N.B. prepared retroviruses; and A.F.S. contributed to the concept, designed the experiments, analyzed the data, wrote the manuscript, and provided financial support.

\section{SUPPLEMENTARY MATERIALS}

www.sciencemag.org/content/354/6311/459/suppl/DC1 Materials and Methods

Figs. S1 to S7

References (38-41)

14 January 2016; accepted 16 September 2016 10.1126/science.aaf2156

\section{Climate change: The 2015 Paris Agreement thresholds and Mediterranean basin ecosystems}

\author{
Joel Guiot ${ }^{1 *}$ and Wolfgang Cramer ${ }^{2}$
}

The United Nations Framework Convention on Climate Change Paris Agreement of December 2015 aims to maintain the global average warming well below $2^{\circ} \mathrm{C}$ above the preindustrial level. In the Mediterranean basin, recent pollen-based reconstructions of climate and ecosystem variability over the past 10,000 years provide insights regarding the implications of warming thresholds for biodiversity and land-use potential. We compare scenarios of climate-driven future change in land ecosystems with reconstructed ecosystem dynamics during the past 10,000 years. Only a $1.5^{\circ} \mathrm{C}$ warming scenario permits ecosystems to remain within the Holocene variability. At or above $2^{\circ} \mathrm{C}$ of warming, climatic change will generate Mediterranean land ecosystem changes that are unmatched in the Holocene, a period characterized by recurring precipitation deficits rather than temperature anomalies.

T he United Nations Framework Convention on Climate Change (UNFCCC) Paris Agreement of December 2015 aims "to hold the increase in the global average temperature to below $2{ }^{\circ} \mathrm{C}$ above preindustrial levels and to pursue efforts to limit the temperature increase to $1.5^{\circ} \mathrm{C}$...." For many regions of the world, achieving the global $2^{\circ} \mathrm{C}$ target would still imply substantially higher average temperatures, with daily maxima reaching extreme values (1). Recent $\sim 1^{\circ} \mathrm{C}$ warming has caused damage in many systems already today (2). The degree to which future damage could be avoided by ambitious warming thresholds is uncertain. Regional temperatures in the

${ }^{1}$ Aix-Marseille Université, CNRS, Institut de Recherche pour le Développement (IRD), Collège de France, Centre Européen de Recherche et d'Enseignement de Géosciences

de l'Environnement (CEREGE), Ecosystèmes Continentaux et Risques Environnementaux (ECCOREV), Aix-en-Provence, France. ${ }^{2}$ Mediterranean Institute for Biodiversity and Ecology (IMBE), Aix-Marseille Université, CNRS, IRD, Avignon

University, 13545 Aix-en-Provence, France.

*Corresponding author. Email: guiot@cerege.fr
Mediterranean basin are now $\sim 1.3^{\circ} \mathrm{C}$ higher than during 1880-1920, compared with an increase of $\sim 0.85^{\circ} \mathrm{C}$ worldwide (Fig. 1). The difference between (global) warming of $1.5^{\circ}$ and $>2{ }^{\circ} \mathrm{C}$ above preindustrial levels is critically important for adaptation policies in the Mediterranean region, notably with respect to land-use systems and the conservation of biodiversity. Simulations with impact models have shed some light on the risks limitations when applied at the regional scale and for low levels of warming (3).

To assess the regional effects of different Paris Agreement thresholds for the Mediterranean basin, the Holocene reconstruction of spatiotemporal ecosystem dynamics from pollen allows the development of reliable scenarios of climate-driven change in land ecosystems (4). Despite the effects of human land use, broader-scale past ecosystem dynamics have been mostly driven by regional climate change.

Mediterranean basin ecosystems are a hot spot of the world's biodiversity (5) and supply numerous services to people, including clean and sensitivities to climate change, but they face water, flood protection, carbon storage, and recreation. Thus, the broad-scale vulnerability of ecosystems to climate change can be used as an indicator of the importance of the warming thresholds identified by the Paris Agreement for the environment and human well-being. Given the confidence with which past ecosystems and climate change can be reconstructed from numerous pollen profiles, the development and validation of more reliable numerical models for the ecosystem-climate relationship have become possible. We apply such an approach to future climate conditions, using simulations from the Coupled Model Intercomparison Project phase 5 (CMIP5) for three different greenhouse gas (GHG) forcings [see table S2 and (6) for details]. An analysis of the annual mean temperatures for these three scenarios for all climate models at the global and Mediterranean scale, an observational time series, and a spatiotemporal historical reconstruction at the Mediterranean scale (Fig. 1) indicate that (i) the projected warming in the Mediterranean basin exceeds the global trend for most simulations; (ii) the first decade of the 21st century has already surpassed the Holocene temperature variability; (iii) the global warming, but also the regional warming, is approximately a linear function of the $\mathrm{CO}_{2}$ concentration; and (iv) only a few simulations provide global warming lower than $2^{\circ} \mathrm{C}$ at the end of the 21st century.

Mediterranean land ecosystems are sensitive not only to warming but also to changes in water availability. Even if past variations in precipitation and their projections for the future are spatially more heterogeneous than temperature fields (7), for most scenarios, the changes in both fields will combine to reduce water availability and trigger losses of Mediterranean ecosystems and their biodiversity during the coming decades (8-10). During the Holocene (especially in the second half of this epoch), periods of precipitation deficits have occurred, but in contrast to the 21st-century situation, temperatures did not rise above the present average (Fig. 1) (4). These periods of precipitation deficits $[\sim 6$ to $\sim 5.2, \sim 4.2$ to $\sim 4$, and $\sim 3.1$ to $\sim 2.9$ thousand years before the present (yr B.P.)] have been identified as possible 
Fig. 1. Annual temperature change (from the preindustrial mean) versus $\mathrm{CO}_{2}$ atmospheric concentrations. Colored boxes represent the Intergovernmental Panel on Climate Change RCP scenarios for 2010-2100 (25th, 50th, and 75th percentiles): RCP2.5 (green), RCP4.5 (orange), and RCP8.5 (red). Solid blue circles with vertical bars concern the same three scenarios for the Mediterranean region $\left(10^{\circ} \mathrm{W}\right.$ to $45^{\circ} \mathrm{E}, 28^{\circ} \mathrm{N}$ to $\left.48^{\circ} \mathrm{N}\right)$. For the Holocene, the blue circles with cyan error bars $(1 \sigma)$ are derived from climate reconstructions from pollen for each century from 10,000 to $100 \mathrm{yr}$ B.P. by steps of 100 years (4) (the variability is multiplied by a factor of 3 to account for the fact that the time resolution is 100 years instead of 10-year averages for the scenarios). The vertical bars represent the \pm 1 SDs provided by the reconstruction method. The mediumsized 1901-2009 circles are the Climatic Research Unit TS3.1 gridded observations (20) averaged in the same area and smoothed with a time step of 10 years. The vertical bars represent the corresponding SDs. The horizontal lines indicate the preindustrial mean temperature and the three thresholds referred to in the Paris Agreement $\left(1.5^{\circ}, 2^{\circ}\right.$, and $\left.3^{\circ} \mathrm{C}\right)$. The black regression line is based on the three global scenarios. ppmv, parts per million by volume.

causes of declines or collapses in civilization in the eastern Mediterranean region (11-13). A recent study (14) has attributed important crop failures in Syria to two strong drought episodescharacterized by a lack of precipitation (reduced by up to $30 \%$ in the 6 -month winter season) and high temperatures (warming of $0.5^{\circ}$ to $1.0^{\circ} \mathrm{C}$ in the annual mean relative to the 20th-century average)-in the eastern Mediterranean between 1998 and 2010. The 1998-2012 period was the driest of the last 500 years (15). Even if societal
Annual temperature: Holocene to late 21st century

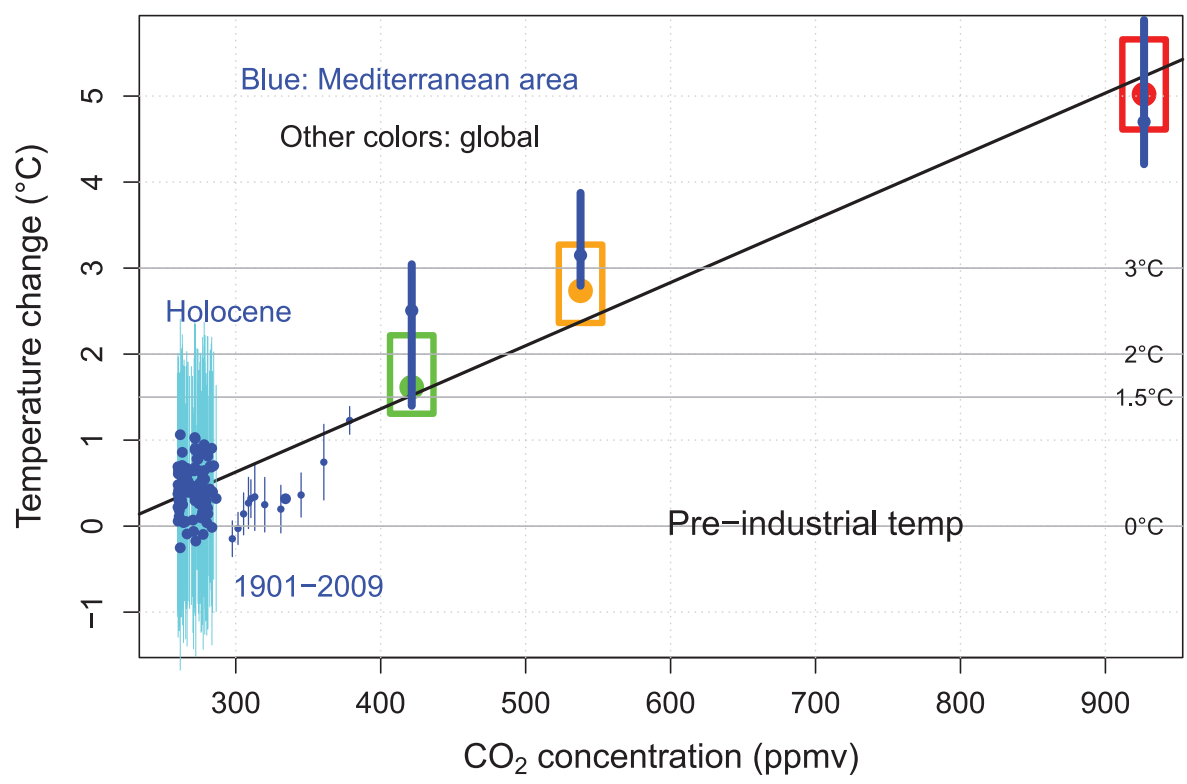

$\mathrm{CO}_{2}$ concentration (ppmv)

\section{Biome type change vs Present}

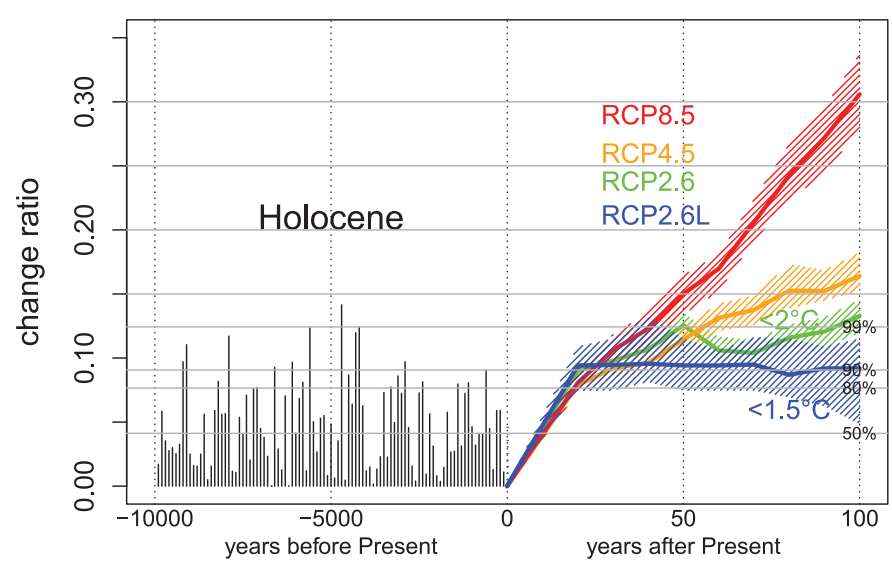

Fig. 2. Proportion of grid cells with a biome change relative to the preindustrial period for the Mediterranean area $\left(10^{\circ} \mathrm{W}\right.$ to $45^{\circ} \mathrm{E}, 2^{\circ} \mathrm{N}$ to $\left.48^{\circ} \mathrm{N}\right)$. The horizontal axis represents the time scale, in years before the present (20th century) for the past (negative numbers) and in years after the present (CE 2000-2010) for the future (positive numbers). Holocene biomes (in black) are based on reconstructions from pollen data (4). Colored lines are given by the BIOME4 model as applied to the RCP projections (see text). Horizontal lines represent the 50th, 80th, 90th, and 99th percentiles of the Holocene values. The colored areas illustrate the interquartile interval provided by the intermodel variability. tion of past climate-vegetation equilibria. Direct human impacts, such as the cultivation of crops or degradation processes, are not taken into account. For the Holocene, BIOME4 was inverted to generate gridded climate patterns by time steps of 100 years and associated ecosystems ("biomes") from pollen records (4). For the future, the forward application of the same model yields ecosystem distributions from climate projections (6). The limitations of a relatively simple ecosystem model are largely offset by two factors. First, this method directly relates the physical environment, including its seasonal variability, and atmospheric $\mathrm{CO}_{2}$ to plant processes and thereby avoids the strong assumptions made by niche models (18). Second, past observations are analyzed with the same processbased model that is used for the future projections, thus providing a more coherent framework for the assessment.

Figure 2 indicates reconstructed and estimated shifts in the distribution of major Mediterranean biomes (temperate conifer forest, deciduous forest, warm mixed forest, xerophytic shrubland, and steppe) over time for the past and future, relative to their current distribution. During the Holocene, only up to $15 \%$ of the land has had different ecosystems from those existing today at any moment. The $10 \%$ level was exceeded only during eight 100-year time slices, and all of these periods occurred before $4200 \mathrm{yr}$ B.P. All of these were relatively humid periods, which became less frequent after this date (4). The past four millennia, and notably the past century, were generally dry compared with the first half of the Holocene.

The future is represented by the following three classes of simulated time-space fields 

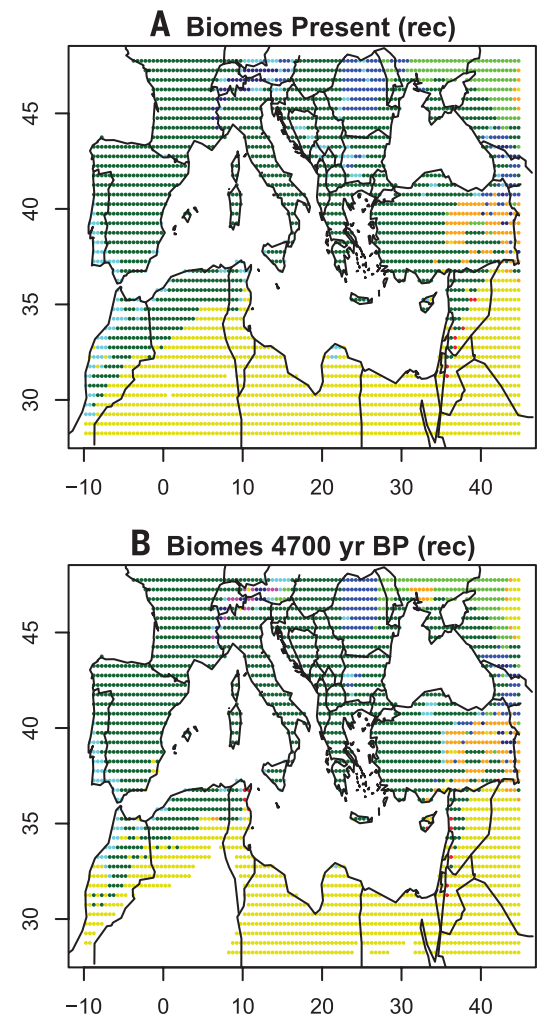

C Simulated Biomes (Present)

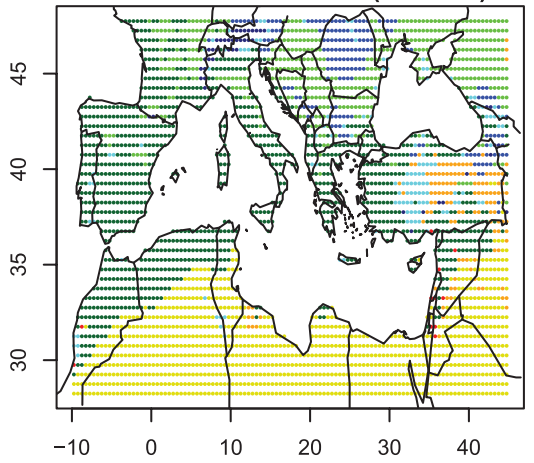

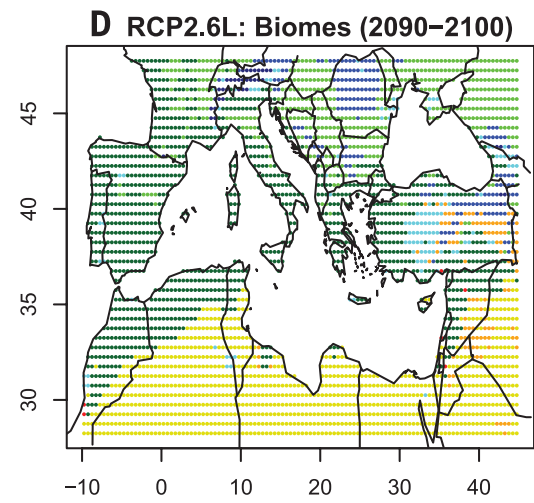

E RCP2.6: Biomes (2090-2100)

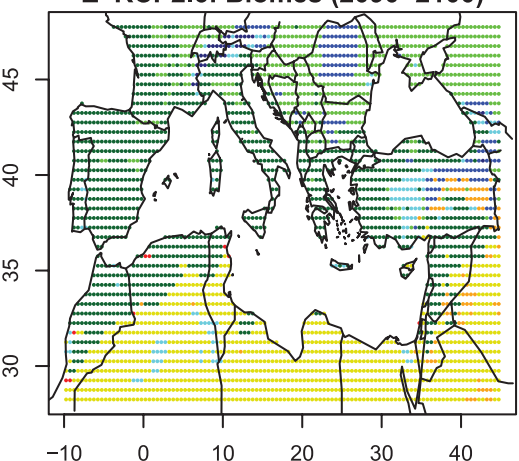

F RCP4.5: Biomes (2090-2100)

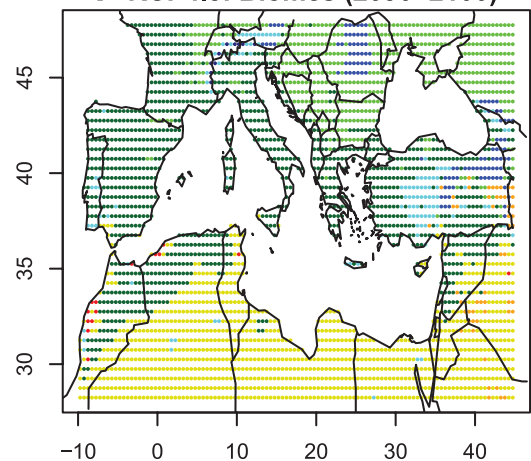

G RCP8.5: Biomes (2090-2100)

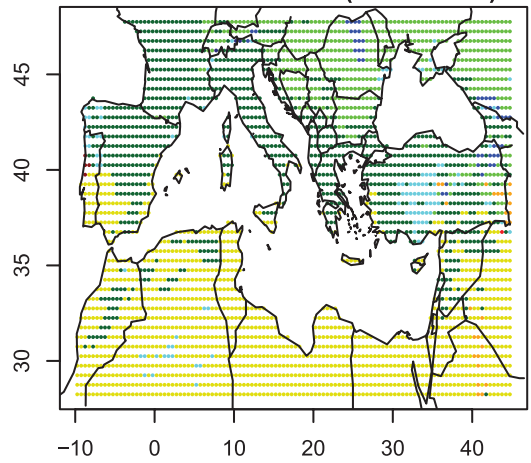

Biome legend

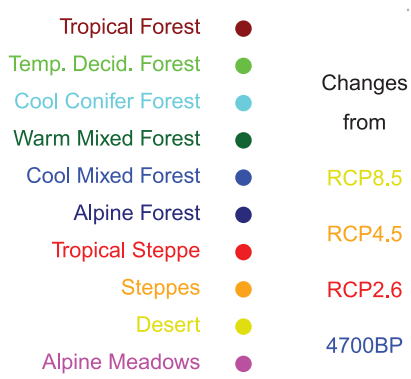

$\mathrm{H}$ Nb different scenarios

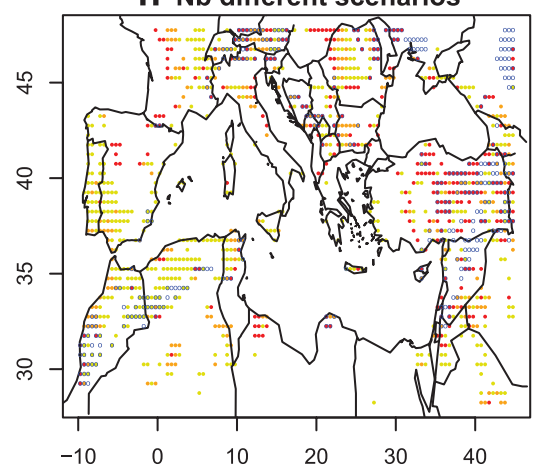

Fig. 3. Mediterranean biome maps. Distribution of Mediterranean biomes (A) reconstructed (rec) from pollen for the present; (B) reconstructed from pollen for 4700 yr B.P.; (C) simulated by the BIOME4 model for the present; and (D to G) for scenarios RCP2.6L, RCP2.6, RCP4.5, and RCP8.5, respectively, at the end of the 21st century. For the simulations, each point indicates the most frequent biome in the ensemble of CMIP5 climate simulations. Map (H) indicates, for each point, the number of scenarios different from the simulated present. Yellow areas indicate when only RCP8.5 is different; orange areas denote when RCP4.5 and RCP8.5 are different; red areas indicate when RCP2.6, RCP4.5, and RCP8.5 are different; and blue circles mark areas in which the biome type at $4700 \mathrm{yr}$ B.P. is different from the present biome type.

of temperature and rainfall, which are derived from the CMIP5 project (table S2): Representative Concentration Pathway 8.5 (RCP8.5) (22 simulations), RCP4.5 (23 simulations), and RCP2.6 (16 simulations). RCP2.6 approximates the $2^{\circ} \mathrm{C}$ target. To assess the $1.5^{\circ} \mathrm{C}$ target, we created a fourth class (denoted RCP2.6L) from selected CMIP5 scenarios [see (6) for details]. Up to 2030, all four classes generate similar ecosystem distributions and generally remain within the bounds of Holocene fluctuations. By the end of the 21st century, RCP2.6L remains in the range of the 80th and 99th percentiles of the Holocene, whereas RCP2.6 simulates Mediterranean ecosystems as they were during the most extreme period of the Holocene (at 4700 yr B.P.), with a change of 12 to $15 \%$.

The limits of the Mediterranean vegetation types defined by biogeographers (19) broadly coincide with our simulated warm mixed forest biome (Fig. 3A), with the following two exceptions: (i) Simulated warm mixed forests also extend to the Atlantic Ocean in the west of France, indicating the inability of BIOME4 to distinguish Atlantic pine forests, and (ii) the narrow strip of Mediterranean vegetation on the Libyan and Egyptian coast, which is below the spatial resolution of our climatic data. The reconstruction for the period of the Holocene (4700 yr B.P.) (Fig. 3B) with the greatest difference from today (Fig. $3 \mathrm{~A})$ shows that the main differences are related to the further regression of forested areas in the southern Mediterranean associated with expanding desert areas.

Simulations for the RCP2.6L and RCP2.6 scenarios do not change biome distributions much at the end of the 21st century (Fig. 3, D to E). However, for the same period, the RCP4.5 scenario induces desert extension toward North Africa, the regression of alpine forests, and the extension of Mediterranean sclerophyllous vegetation. Under the RCP8.5 scenario, all of 
southern Spain turns into desert, deciduous forests invade most of the mountains, and Mediterranean vegetation replaces most of the deciduous forests in a large part of the Mediterranean basin. Figure $3 \mathrm{H}$ illustrates the variation from areas without any changes, regardless of scenario (stable white areas), to areas in which changes from scenario RCP2.6 already appear (red areas). As expected, the most-sensitive areas are those located at the limit between two biomesfor example, in the mountains at the transition between temperate and montane forest or in the southern Mediterranean at the transition between forest and desert biomes. The map for $4700 \mathrm{yr}$ B.P., in which the past changes were among the highest (Fig. 3B), has the largest changes in the southwest, eastern steppe areas, and the mountains, but these changes are relatively sparse.

Our analysis shows that, in approximately one century, anthropogenic climate change without ambitious mitigation policies will likely alter ecosystems in the Mediterranean in a way that is without precedent during the past 10 millennia. Despite known uncertainties in climate models, GHG emission scenarios at the level of country commitments before the UNFCCC Paris Agreement will likely lead to the substantial expansion of deserts in much of southern Europe and northern Africa. The highly ambitious RCP2.6 scenario seems to be the only possible pathway toward more limited impacts. Only the coldest RCP2.6L simulations, which correspond broadly to the $1.5^{\circ} \mathrm{C}$ target of the Paris Agreement, allow ecosystem shifts to remain inside the limits experienced during the Holocene.

This analysis does not account for other human impacts on ecosystems, in addition to climate change (i.e., land-use change, urbanization, soil degradation, etc.), which have grown in importance after the mid-Holocene and have become dominant during the past centuries. Many of these effects are likely to become even stronger in the future because of the expanding human population and economic activity. Most land change processes reduce natural vegetation or they seal or degrade the soils, representing additional effects on ecosystems, which will enhance, rather than dampen, the biome shifts toward a drier state than estimated by this analysis. This assessment shows that, without ambitious climate targets, the potential for future managed or unmanaged ecosystems to host biodiversity or deliver services to society is likely to be greatly reduced by climate change and direct local effects.

\section{REFERENCES AND NOTES}

1. S. I. Seneviratne, M. G. Donat, A. J. Pitman, R. Knutti, R. L. Wilby, Nature 529, 477-483 (2016).

2. W. Cramer et al., in Climate Change 2014: Impacts, Adaptation, and Vulnerability. Part A: Global and Sectoral Aspects. Contribution of Working Group II to the Fifth Assessment Report of the Intergovernmental Panel on Climate Change, C. B. Field et al., Eds. (Cambridge Univ. Press, 2014). pp. 979-1037.

3. C.-F. Schleussner et al., Earth Syst. Dyn. Discuss. 6 , 2447-2505 (2015).

4. J. Guiot, D. Kaniewski, Front. Earth Sci. 3, 28 (2015).
F. Médail, N. Myers, in Hotspots Revisited: Earth's Biologically Richest and Most Endangered Terrestrial Ecoregions, R. A. Mittermeier et al., Eds. (Conservation International, 2004), pp. 144-147.

6. Materials and methods are available as supplementary materials on Science Online.

7. E. Xoplaki, J. F. González-Rouco, J. Luterbacher, H. Wanner, Clim. Dyn. 23, 63-78 (2004)

8. L. Maiorano et al., Philos. Trans. R. Soc. London Ser. B 366 , 2681-2692 (2011)

9. T. Keenan, J. Maria Serra, F. Lloret, M. Ninyerola, S. Sabate, Glob. Change Biol. 17, 565-579 (2011).

10. W. Thuiller, S. Lavorel, M. B. Araújo, Glob. Ecol. Biogeogr. 14 347-357 (2005)

11. B. Weninger et al., Doc. Praehist. 36, 7-59 (2009)

12. D. Kaniewski, E. Van Campo, H. Weiss, Proc. Natl. Acad. Sci. U.S.A. 109, 3862-3867 (2012).

13. N. Roberts, D. Brayshaw, C. Kuzucuoglu, R. Perez, L. Sadori, Holocene 21, 3-13 (2011).

14. C. P. Kelley, S. Mohtadi, M. A. Cane, R. Seager, Y. Kushnir, Proc. Natl. Acad. Sci. U.S.A. 112, 3241-3246 (2015)

15. B. I. Cook, K. J. Anchukaitis, R. Touchan, D. M. Meko,

E. R. Cook, J. Geophys. Res. 121, 2060-2074 (2016).

16. G. Middleton, J. Archaeol. Res. 20, 257-307 (2012).

17. A. B. Knapp, S. W. Manning, Am. J. Archaeol. 120, 99-149 (2016)

18. C. B. Yackulc, J. D. Nichols, J. Reid, R. Der, Ecology 96, 16-23 (2015)

19. C. Roumieux et al., Ecol. Mediterr. 36, 17-24 (2010).

20. I. Harris, P. D. Jones, T. J. Osborn, D. H. Lister, Int. J. Climatol. 34, 623-642 (2014)

\section{ACKNOWLEDGMENTS}

The authors are members of the Observatoire des Sciences de I'Univers Pytheas Institute and the ECCOREV network. This research has been funded by Labex OT-Med (project ANR-11 LABEX-0061), the "Investissements d'Avenir" French government project of the French National Research Agency (ANR), AMidex (project 11-IDEX-0001-02), and the European Union FP7-ENVIRONMENT project OPERAs (grant 308393). We acknowledge the World Climate Research Programme's Working Group on Coupled Modelling, which is responsible for CMIP, and we thank the climate modeling groups (table S2) for producing and making their model outputs available. For CMIP, the U.S. Department of Energy's Program for Climate Model Diagnosis and Intercomparison provides coordinating support and led the development of software infrastructure, in partnership with the Global Organization for Earth System Science Portals. R. Suarez and S. Shi have extracted and preprocessed the model simulations. Holocene climate reconstructions are available at http://database.otmed.fr/ geonetworkotmed/srv/eng/search - |54b9bf34-57ae-45ea-b4559f90351e538f. Future climate projections are available at http://cmip-pcmdi.Inl.gov/cmip5/.

\section{SUPPLEMENTARY MATERIALS}

www.sciencemag.org/content/354/6311/465/suppl/DC1

Materials and Methods

Table S1 and S2

References (21-28)

\title{
GENE EXPRESSION
}

\section{Xist recruits the $X$ chromosome to the nuclear lamina to enable chromosome-wide silencing}

\author{
Chun-Kan Chen, ${ }^{1}$ Mario Blanco, ${ }^{1}$ Constanza Jackson, ${ }^{1}$ Erik Aznauryan, ${ }^{1}$ \\ Noah Ollikainen, ${ }^{1}$ Christine Surka, ${ }^{1}$ Amy Chow, ${ }^{1}$ Andrea Cerase, ${ }^{2}$ \\ Patrick McDonel, ${ }^{3}$ Mitchell Guttman ${ }^{1 *}$
}

The Xist long noncoding RNA orchestrates $\mathrm{X}$ chromosome inactivation, a process that entails chromosome-wide silencing and remodeling of the three-dimensional (3D) structure of the $\mathrm{X}$ chromosome. Yet, it remains unclear whether these changes in nuclear structure are mediated by Xist and whether they are required for silencing. Here, we show that Xist directly interacts with the Lamin B receptor, an integral component of the nuclear lamina, and that this interaction is required for Xist-mediated silencing by recruiting the inactive $X$ to the nuclear lamina and by doing so enables Xist to spread to actively transcribed genes across the $X$. Our results demonstrate that lamina recruitment changes the 3D structure of DNA, enabling $X i s t$ and its silencing proteins to spread across the $X$ to silence transcription.

I he Xist long noncoding RNA (lncRNA) initiates $\mathrm{X}$ chromosome inactivation (XCI), a process that entails chromosome-wide transcriptional silencing (I) and large-scale remodeling of the three-dimensional (3D) structure of the X chromosome (2-4), by spreading across the future inactive $\mathrm{X}$ chromosome and excluding RNA polymerase II (PolII) $(1,5)$. Xist initially localizes to genomic DNA regions on the $\mathrm{X}$ chromosome that are not actively transcribed $(6-8)$, before spreading to actively transcribed genes (7-9). Deletion of a highly conserved region of Xist that is required for transcrip- tional silencing, called the A-repeat (10), leads to a defect in Xist spreading (7) and spatial exclusion of active genes from the Xist-coated nuclear compartment (9). Whether these structural changes are required for, or merely a consequence of, transcriptional silencing mediated by the A-repeat of Xist remains unclear $(7,9)$. Recently, we and others identified by means of mass spectrometry the proteins that interact with Xist (11-13). One of these proteins is the Lamin B receptor (LBR) (11, 13), a transmembrane protein that is anchored in the inner nuclear membrane, binds to Lamin B, 


\section{Science $\triangle 1$ AAAS}

EXTENDED PDF FORMAT SPONSORED BY

Sample-Size Antibodies Now Available

n) Learn More R D sYSTEMS

www.rndsystems.com
Climate change: The 2015 Paris Agreement thresholds and Mediterranean basin ecosystems

Joel Guiot and Wolfgang Cramer (October 27, 2016)

Science 354 (6311), 465-468. [doi: 10.1126/science.aah5015]

Editor's Summary

\section{A warming limit for the Mediterranean basin}

Pollen cores from sediments provide rich detail on the history of vegetation and climate in the Mediterranean during the Holocene (the most recent 10,000 years). Guiot and Cramer used this information as a baseline against which to compare predictions of future climate and vegetation under different climate-change scenarios. Vegetation and land-use systems observed in the Holocene records may persist under a $1.5^{\circ} \mathrm{C}$ warming above preindustrial temperature levels. A $2^{\circ} \mathrm{C}$ warming, however, is likely over the next century to produce ecosystems in the Mediterranean basin that have no analog in the past 10,000 years.

Science, this issue p. 465

This copy is for your personal, non-commercial use only.

Article Tools Visit the online version of this article to access the personalization and article tools:

http://science.sciencemag.org/content/354/6311/465

Permissions Obtain information about reproducing this article:

http://www.sciencemag.org/about/permissions.dtl

Science (print ISSN 0036-8075; online ISSN 1095-9203) is published weekly, except the last week in December, by the American Association for the Advancement of Science, 1200 New York Avenue NW, Washington, DC 20005. Copyright 2016 by the American Association for the Advancement of Science; all rights reserved. The title Science is a registered trademark of AAAS. 


\title{
Science \\ МIAAAS
}

\section{Supplementary Materials for}

\section{Climate change: The 2015 Paris Agreement thresholds and Mediterranean basin ecosystems}

\author{
Joel Guiot* and Wolfgang Cramer \\ *Corresponding author. Email: guiot@cerege.fr \\ Published 28 October 2016, Science 354, 465 (2016)
}

DOI: $10.1126 /$ science.aah5015

This PDF file includes:

Materials and Methods

Tables S1 and S2

References 


\section{Materials and Methods}

The reconstruction of Holocene climate and biomes (4) is based on the process-based equilibrium terrestrial biosphere model BIOME4 (21), which has been used in numerous regional to global scale studies (22). This model predicts structure and productivity of broadscale land ecosystems from monthly temperature and rainfall values and annual $\mathrm{CO}_{2}$ concentration. It uses a photosynthesis scheme that simulates acclimation of plants to changed atmospheric $\mathrm{CO}_{2}$ by optimization of nitrogen allocation to foliage and by accounting for the effects of $\mathrm{CO}_{2}$ on net assimilation, stomatal conductance, leaf area index (LAI) and ecosystem water balance. BIOME4 is based on sufficiently simple descriptions of ecophysiological processes to allow broad-scale application. It represents substantial advantages over nichemodels because it has not been tuned to reproduce present-day potential vegetation, but rather to simulate correctly the main processes underlying the potential vegetation distribution which are assumed to have been similar throughout the Holocene. BIOME4 does not account for human land use.

The inputs of the model are monthly average / total values of temperature, precipitation and cloudiness percentage, atmospheric $\mathrm{CO}_{2}$ concentration, and (static) soil texture. The outputs include net primary production (NPP) of each of the potentially occurring 13 plant functional types (PFT), and the corresponding 'biome type', from a set of 28 broad categories (Table S1). To obtain a robust classification of ecosystem types suitable for the analysis of Mediterranean vegetation, compatible with current biogeographical knowledge of potential natural vegetation in the region (23), the 28 biome types provided by BIOME4 were aggregated into 11 groups (Table S1).

For the Holocene, pollen records from a large number of sources, initially percentages of a number of taxa (which can be species, genera or families according to possibilities of morphological differentiation), are grouped into pollen plant functional types (PFT) scores according to the "biomization" method adapted by (24). Using these data, BIOME4 is run in inverse mode, i.e. a large number of randomized climate conditions are tried at each time step and for each grid cell. For each of these, the NPP of all 13 PFT's is compared to PFT scores calculated from pollen (4). The climate conditions for which the simulated NPP matches best with the pollen-derived PFTs scores provide the reconstruction and hence the corresponding biome type. The atmospheric $\mathrm{CO}_{2}$ concentration is provided by the ice cores at Taylor Dome, Antarctica (25) and the soil parameters are kept to the present values. Since the spatiotemporal patterns reflected by pollen diagrams are also influenced by historic land use, the reconstruction also reflects direct human impacts on ecosystems, however this effect is assumed to be relatively minor for most of the Holocene. Model outputs in this study are gridded climate and biome types on a coarse grid of $2^{\circ}$ in latitude and $4^{\circ}$ in longitude. To allow for direct comparison of reconstructed and projected biome patterns, we have interpolated the reconstructions to a common $1^{\circ} \times 1^{\circ}$ resolution.

For future projections, we use BIOME4 in forward mode, i.e. scenarios from climate simulations under different scenarios are used as inputs yielding the biome type generated by this climate. We use temperature and rainfall outputs from climate models assembled in CMIP5 (26), forced by three greenhouse gas radiative forcing (Representative Concentration Pathways, RCP) (27). RCP8.5 (GHG radiative forcing $<8.5 \mathrm{~W} / \mathrm{m}^{2}$ ) is the "business as usual" scenario. RCP4.5 corresponds to policies to maintain GHG radiative forcing below $4.5 \mathrm{~W} / \mathrm{m}^{2}$ and approximates the effort of mitigation contained in the intended nationally determined contributions (INDC) proposed by the governments at the Paris COP21. RCP2.6 corresponds to more ambitious mitigation policies, with a GHG radiative forcing constrained to remain 
below $2.6 \mathrm{~W} / \mathrm{m}^{2}$. It is the only one able to limit the global warming to $2{ }^{\circ} \mathrm{C}$. Constrained by the availability of simulation outputs in the CMIP5 archive, we use between 16 and 23 simulations performed by 13 climate modeling centers (Table S2). We also use for BIOME4 the atmospheric $\mathrm{CO}_{2}$ concentrations related to these scenarios.

To correct for climate model bias and differences in spatial resolution, we use anomalies (projection minus control) of monthly temperature and precipitation values from all simulations. The anomalies are interpolated to a common grid of $1 \times 1^{\circ}$ of longitude and latitude (2997 land grid cells for the Mediterranean basin) and then added to the present climate normal given by the CRU TS 3.23 data file (20). Climate projections from 2010 to 2100 are used as decadal monthly averages.

The mean global temperature simulated for the last $21^{\text {st }}$ century decade under the RCP2.6 scenario is about $2{ }^{\circ} \mathrm{C}$ above the pre-industrial temperature (Fig. 1). Among the simulations available, only two keep global warming below $1.5^{\circ} \mathrm{C}$ throughout the $21^{\text {st }}$ century. To be able to calculate uncertainties based on realistic inter-model dispersion, we have constructed an additional low-warming scenario with variability comparable to the three RCP groups by selecting from all other 16 simulations those decades for which global warming happens to be lower than $1.5^{\circ} \mathrm{C}$. Assuming that the effect of changes in time-lagged systems such as largescale ocean circulations are negligible (3), we adopt the following procedure: (i) for each decade of the $21^{\text {st }}$ century, we build a theoretical Gaussian probability distribution $\mathrm{N}\left(1.2^{\circ} \mathrm{C}_{2}\right.$ $S_{k}$ ) of the global mean temperature anomaly where $S_{k}$ is the standard deviation of the 16 global temperature simulations for decade k; (ii) we then sample a large number (say 1000) values from this distribution; (iii) each of these 1000 values is approximated by the closest simulation from the 16 original simulations of the ten decades. This provides a set of 1000 simulations compatible with the $+1.5^{\circ} \mathrm{C}$ threshold called RCP2.6L, which will be used for calculating the most probable biome in each grid cell.

BIOME4 is driven by monthly temperature and precipitation fields interpolated from climate model simulations; the monthly cloudiness (\%) fields are calculated by linear regression from the temperature and precipitation values (28); the soil parameters are kept to the present values. We use the $\mathrm{CO}_{2}$ atmospheric concentration time-series used by CMIP5 (27). High levels of $\mathrm{CO}_{2}$ enable to enhance photosynthesis and to increase the water use efficiency of the vegetation. These processes, not discussed here, are taken into account in the future projections of biome type distribution, as they may partly compensate the increase of evapotranspiration projected for the future. Examples of biome maps are given in Fig. 3.

To estimate the magnitude of the effect of climatic change on the aggregated 11 ecosystem types, we calculate the number of biome type changes across the 2997 grid cells for each of the model simulations relative to the estimated current distribution, i.e. the simulation at 2000-2010 by RCP2.6 for the future scenarios (Fig.3A) and the reconstruction based on the CRU TS 3.23 climate field (Fig. 3E). The time-series of biome changes are given in Fig. 2: the Holocene changes by steps of 100 years for the past (10,000 to 0 years BP) and the future changes by steps of 10 years for the future ( 0 to 100 years after Present).

The uncertainties on the projections are restricted to the dispersion between the climate simulations which are directly propagated to the proportions of biome type changes. There is no possibility to take into account the deviations between the mean climate simulation and the true climate, nor those between simulated and true vegetation. For the Holocene, the method enables to calculate the uncertainties on the climate reconstructions (see the error bars for the annual temperature in Fig. 1), but not on the biome type. We assume that the temporal variability of the biome type changes is a better estimate of the biome uncertainty than the within grid cell variability. 
Fig. 3 illustrates this design. The maps have a resolution of $1^{\circ} \times 1^{\circ}$. Fig. $3 \mathrm{~A}$ is obtained from BIOME4 inversion based on present day (last century) pollen data. Fig. 3B is obtained in the same way for the pollen data on the 4650-4750 yr BP time slice. The grid cells where the biome type has changed between both periods are indicated with blue circles in Fig. $3 \mathrm{H}$. The changes are mainly in Northern Africa at the interface of the desert and in the mountains areas of Near East, Anatolia, the Balkans and the Alps. Fig. 3C represents the biome distribution simulated by BIOME4 from present climate. The main difference with the pollen reconstruction in Fig. 3A is that BIOME4 simulates temperate deciduous forest in many areas where are reconstructed warm mixed forest from pollen. This is likely due to an overrepresentation of pine pollen in pollen data. Fig. 3D, 3E, 3F and 3G are forward biome simulations by BIOME4 from climate projections at the end of the $21^{\text {st }}$ century. The four maps shows the gradient between a " $1.5^{\circ} \mathrm{C}$ world" to a " $4{ }^{\circ} \mathrm{C}$ world" with a progressive extension of deserts and a regression of cool and alpine forest. This is summarized by Fig. $3 \mathrm{H}$, which shows that the proportion of grid cells with a biome change is relatively low with RCP2.6L scenario (7\% in red), increasing to $13 \%$ (in orange) with RCP2.6, to $17 \%$ (in yellow) with RCP4.5 and to $31 \%$ (in yellow) with RCP8.5.

\section{Table S1.}

Correspondence between the biome types simulated by BIOME4 and the aggregated biome types used in this study

\begin{tabular}{|l|l|l|}
\hline $\mathrm{N}^{\circ}$ & BIOME4 type & Aggregated biome type \\
\hline 1 & $\begin{array}{l}\text { Tropical evergreen forest, tropical semi-deciduous } \\
\text { forest, tropical deciduous forest/woodland, temperate } \\
\text { broadleaved savannah }\end{array}$ & Tropical forest \\
\hline 2 & Temperate deciduous forest, temperate conifer forest & Temperate deciduous forest \\
\hline 3 & $\begin{array}{l}\text { Warm mixed forest, temperate xerophytic shrubland, } \\
\text { temperate sclerophyll woodland }\end{array}$ & Warm mixed forest \\
\hline 4 & Cool mixed forest & Cool mixed forest \\
\hline 5 & Cool conifer forest, open conifer woodland & Cool conifer forest \\
\hline 6 & $\begin{array}{l}\text { Evergreen taiga/montane forest, deciduous } \\
\text { taiga/montane forest, cold mixed forest, boreal parkland }\end{array}$ & Alpine forest (taiga) \\
\hline 7 & Tropical grassland, tropical savannah & Tropical steppes \\
\hline 8 & Desert, tropical xerophytic shrubland & Desert \\
\hline 9 & Temperate grassland & Temperate steppes \\
\hline 10 & $\begin{array}{l}\text { Steppe tundra, shrub tundra, dwarf shrub tundra, } \\
\text { prostrate shrub tundra, cushion forb lichen moss tundra }\end{array}$ & Alpine meadows (tundra) \\
\hline 11 & Barren, land ice & Barren soil, ice \\
\hline
\end{tabular}


Table S2.

CMIP5 simulations (code of model, institute name); crosses indicate if the model is used for the scenario.

\begin{tabular}{|c|c|c|c|c|}
\hline Model & Institute & RCP2.6 & RCP4.5 & RCP8.5 \\
\hline bcc-csm1-1 & Beijing Climate Center, China Meteorological Administration & $\mathrm{X}$ & $\mathrm{X}$ & $\mathrm{X}$ \\
\hline bcc-csm1-1-m & Beijing Climate Center, China Meteorological Administration & $\mathrm{X}$ & $\mathrm{X}$ & $\mathrm{X}$ \\
\hline CanESM2 & Canadian Centre for Climate modelling, Canada & $\mathrm{X}$ & $\mathrm{X}$ & $\mathrm{X}$ \\
\hline CESM1-BGC & $\begin{array}{l}\text { Community Earth System Model Contributors, NSF-DOE- } \\
\text { NCAR, USA }\end{array}$ & & $\bar{X}$ & \\
\hline CESM1-CAM5 & $\begin{array}{l}\text { Community Earth System Model Contributors, NSF-DOE- } \\
\text { NCAR, USA }\end{array}$ & & $\bar{X}$ & \\
\hline CMCC-CM & Centro Euro-Med per Cambiamenti Climatici, Italy & & $\mathrm{X}$ & $\mathrm{X}$ \\
\hline CMCC-CMS & Centro Euro-Med per Cambiamenti Climatici, Italy & & $\mathrm{X}$ & $\mathrm{X}$ \\
\hline CMCC-CESM & Centro Euro-Med per Cambiamenti Climatici, Italy & & & $\mathrm{X}$ \\
\hline CNRM-CM5 & $\begin{array}{l}\text { Centre National de Recherches Météorologiques / Centre } \\
\text { Européen de Recherche et Formation Avancée en Calcul } \\
\text { Scientifique, France }\end{array}$ & $\mathrm{X}$ & $\mathrm{X}$ & $\mathrm{X}$ \\
\hline GFDL-CM3 & NOAA Geophysical Fluid Dynamics Laboratory, USA & $\mathrm{X}$ & $\bar{X}$ & \\
\hline GISS-E2-H & NASA Goddard Institute for Space Studies, USA & $\mathrm{X}$ & $\mathrm{X}$ & \\
\hline GISS-E2-H-CC & NASA Goddard Institute for Space Studies, USA & & $\mathrm{X}$ & $\mathrm{X}$ \\
\hline GISS-E2-R & NASA Goddard Institute for Space Studies, USA & $\bar{X}$ & $\bar{X}$ & $\mathrm{X}$ \\
\hline GISS-E2-R-CC & NASA Goddard Institute for Space Studies, USA & & & $\mathrm{X}$ \\
\hline HadGEM2-AO & Met-Office - Hadley Center, UK & $\mathrm{X}$ & $\mathrm{X}$ & $\mathrm{X}$ \\
\hline HadGEM2-CC & Met-Office - Hadley Center, UK & & $\bar{X}$ & \\
\hline HadGEM2-ES & $\begin{array}{l}\text { Met-Office - Hadley Center, contributed by Instituto Nacional } \\
\text { de Pesquisas Espaciais, Spain }\end{array}$ & $\mathrm{X}$ & & $\mathrm{X}$ \\
\hline $\begin{array}{l}\text { HadGEM2-ES- } \\
\text { CC }\end{array}$ & $\begin{array}{l}\text { Met-Office - Hadley Center, contributed by Instituto Nacional } \\
\text { de Pesquisas Espaciais, Spain }\end{array}$ & & & \\
\hline inmem4 & Inst. For Numerical Mathematics, Russia & & $\bar{X}$ & $\mathrm{X}$ \\
\hline IPSL-CM5A-LR & Institut Pierre-Simon Laplace, France & $\mathrm{X}$ & $\mathrm{X}$ & $\mathrm{X}$ \\
\hline $\begin{array}{l}\text { IPSL-CM5A- } \\
\text { MR }\end{array}$ & Institut Pierre-Simon Laplace, France & $\mathrm{X}$ & $\bar{X}$ & $\mathrm{X}$ \\
\hline IPSL-CM5B-LR & Institut Pierre-Simon Laplace, France & & $\bar{X}$ & $\mathrm{X}$ \\
\hline MPI-ESM-LR & Max-Planck Inst. für Meteorologie, Germany & $\mathrm{X}$ & $\mathrm{X}$ & $\mathrm{X}$ \\
\hline MPI-ESM-MR & Max-Planck Inst. für Meteorologie, Germany & $\mathrm{X}$ & $\mathrm{X}$ & $\mathrm{X}$ \\
\hline MRI-CGCM3 & Meteorological Research Institute, Japan & $\mathrm{X}$ & $X$ & $\mathrm{X}$ \\
\hline MRI-ESM1 & Meteorological Research Institute, Japan & & & $\mathrm{X}$ \\
\hline NorESM1-M & Norwegian Climate Centre & $\mathrm{X}$ & $\bar{X}$ & $\mathrm{X}$ \\
\hline NorESM1-ME & Norwegian Climate Centre & $\mathrm{X}$ & $\mathrm{X}$ & $\mathrm{X}$ \\
\hline $\begin{array}{l}\mathrm{Nb} \\
\text { simulations }\end{array}$ & & 16 & 23 & 22 \\
\hline
\end{tabular}




\section{References and Notes}

1. S. I. Seneviratne, M. G. Donat, A. J. Pitman, R. Knutti, R. L. Wilby, Allowable $\mathrm{CO}_{2}$ emissions based on regional and impact-related climate targets. Nature 529, 477-483 (2016).doi:10.1038/nature16542 Medline

2. W. Cramer et al., in Climate Change 2014: Impacts, Adaptation, and Vulnerability. Part A: Global and Sectoral Aspects. Contribution of Working Group II to the Fifth Assessment Report of the Intergovernmental Panel on Climate Change, C. B. Field et al., Eds. (Cambridge Univ. Press, 2014), pp. 979-1037.

3. C.-F. Schleussner, T. K. Lissner, E. M. Fischer, J. Wohland, M. Perrette, A. Golly, J. Rogelj, K. Childers, J. Schewe, K. Frieler, M. Mengel, W. Hare, M. Schaeffer, Differential climate impacts for policy-relevant limits to global warming: The case of $1.5^{\circ} \mathrm{C}$ and $2{ }^{\circ} \mathrm{C}$. Earth Syst. Dyn. Discuss. 6, 2447-2505 (2015). doi:10.5194/esdd-6-2447-2015

4. J. Guiot, D. Kaniewski, The Mediterranean Basin and Southern Europe in a warmer world: What can we learn from the past? Front. Earth Sci. 3, 28 (2015). doi:10.3389/feart.2015.00028

5. F. Médail, N. Myers, in Hotspots Revisited: Earth's Biologically Richest and Most Endangered Terrestrial Ecoregions, R. A. Mittermeier et al., Eds. (Conservation International, 2004), pp. 144-147.

6. Materials and methods are available as supplementary materials on Science Online.

7. E. Xoplaki, J. F. González-Rouco, J. Luterbacher, H. Wanner, Wet season Mediterranean precipitation variability: Influence of large-scale dynamics and trends. Clim. Dyn. 23, 6378 (2004). doi:10.1007/s00382-004-0422-0

8. L. Maiorano, A. Falcucci, N. E. Zimmermann, A. Psomas, J. Pottier, D. Baisero, C. Rondinini, A. Guisan, L. Boitani, The future of terrestrial mammals in the Mediterranean basin under climate change. Philos. Trans. R. Soc. London Ser. B 366, 2681-2692 (2011).doi:10.1098/rstb.2011.0121 Medline

9. T. Keenan, J. Maria Serra, F. Lloret, M. Ninyerola, S. Sabate, Predicting the future of forests in the Mediterranean under climate change, with niche- and process-based models: $\mathrm{CO}_{2}$ matters! Glob. Change Biol. 17, 565-579 (2011). doi:10.1111/j.1365-2486.2010.02254.x

10. W. Thuiller, S. Lavorel, M. B. Araújo, Niche properties and geographical extent as predictors of species sensitivity to climate change. Glob. Ecol. Biogeogr. 14, 347-357 (2005). doi:10.1111/j.1466-822X.2005.00162.X

11. B. Weninger, L. Clare, E. Rohling, O. Bar-Yosef, U. Böhner, M. Budja, M. Bundschuh, A. Feurdean, H. G. Gebe, O. Jöris, J. Linstädter, P. Mayewski, T. Mühlenbruch, A. Reingruber, G. Rollefson, D. Schyle, L. Thissen, H. Todorova, C. Zielhofer, The impact of rapid climate change on prehistoric societies during the Holocene in the Eastern Mediterranean. Doc. Praehist. 36, 7-59 (2009). doi:10.4312/dp.36.2

12. D. Kaniewski, E. Van Campo, H. Weiss, Drought is a recurring challenge in the Middle East. Proc. Natl. Acad. Sci. U.S.A. 109, 3862-3867 (2012).doi:10.1073/pnas.1116304109 $\underline{\text { Medline }}$ 
13. N. Roberts, D. Brayshaw, C. Kuzucuoglu, R. Perez, L. Sadori, The mid-Holocene climatic transition in the Mediterranean: Causes and consequences. Holocene 21, 3-13 (2011). doi: $10.1177 / 0959683610388058$

14. C. P. Kelley, S. Mohtadi, M. A. Cane, R. Seager, Y. Kushnir, Climate change in the Fertile Crescent and implications of the recent Syrian drought. Proc. Natl. Acad. Sci. U.S.A. 112, 3241-3246 (2015).doi:10.1073/pnas.1421533112 Medline

15. B. I. Cook, K. J. Anchukaitis, R. Touchan, D. M. Meko, E. R. Cook, Spatiotemporal drought variability in the Mediterranean over the last 900 years. J. Geophys. Res. 121, 2060-2074 (2016). doi:10.1002/2015JD023929

16. G. Middleton, Nothing lasts forever: Environmental discourses on the collapse of past societies. J. Archaeol. Res. 20, 257-307 (2012). doi:10.1007/s10814-011-9054-1

17. A. B. Knapp, S. W. Manning, Crisis in context: The end of the Late Bronze Age in the Eastern Mediterranean. Am. J. Archaeol. 120, 99-149 (2016). doi:10.3764/aja.120.1.0099

18. C. B. Yackulc, J. D. Nichols, J. Reid, R. Der, To predict the niche, model colonization and extinction. Ecology 96, 16-23 (2015).doi:10.1890/14-1361.1 Medline

19. C. Roumieux et al., Actualisation des limites de l'aire du bioclimat méditerranéen selon les critères de Daget (1977). Ecol. Mediterr. 36, 17-24 (2010).

20. I. Harris, P. D. Jones, T. J. Osborn, D. H. Lister, Updated high-resolution grids of monthly climatic observations - the CRU TS3.10 dataset. Int. J. Climatol. 34, 623-642 (2014). doi:10.1002/joc. 3711

21. J. O. Kaplan et al., Climate change and Arctic ecosystems: 2. Modeling, paleodata-model comparisons, and future projections. J. Geophys. Res. 108, 8171 (2003). doi:10.1029/2002JD002559

22. S. P. Harrison, C. I. Prentice, Climate and $\mathrm{CO}_{2}$ controls on global vegetation distribution at the Last Glacial Maximum: Analysis based on paleovegetation data, biome modelling and paleoclimate simulations. Glob. Change Biol. 9, 983-1004 (2003). doi:10.1046/j.1365-2486.2003.00640.x

23. J. Blondel, J. Aronson, J. Y. Bodiou, G. Boeuf, The Mediterranean Region: Biological Diversity Through Time and Space (Oxford Univ. Press, ed. 2, 2010).

24. P. E. Tarasov, R. Cheddadi, J. Guiot, S. Bottema, O. Peyron, J. Belmonte, V. Ruiz-Sanchez, F. Saadi, S. Brewer, A method to determine warm and cool steppe biomes from pollen data; application to the Mediterranean and Kazakhstan regions. J. Quat. Sci. 13, 335-344 (1998). doi:10.1002/(SICI)1099-1417(199807/08)13:4<335::AID-JQS375>3.0.CO;2-A

25. A. Indermühle, T. F. Stocker, F. Joos, H. Fischer, H. J. Smith, M. Wahlen, B. Deck, D. Mastroianni, J. Tschumi, T. Blunier, R. Meyer, B. Stauffer, Holocene carbon-cycle dynamics based on $\mathrm{CO}_{2}$ trapped in ice at Taylor Dome, Antarctica. Nature 398, 121-126 (1999). doi:10.1038/18158

26. K. E. Taylor, R. J. Stouffer, G. A. Meehl, An overview of CMIP5 and the experiment design. Bull. Am. Meteorol. Soc. 93, 485-498 (2012). doi:10.1175/BAMS-D-11-00094.1 
27. M. Meinshausen, S. J. Smith, K. Calvin, J. S. Daniel, M. L. T. Kainuma, J.-F. Lamarque, K. Matsumoto, S. A. Montzka, S. C. B. Raper, K. Riahi, A. Thomson, G. J. M. Velders, D. P. P. van Vuuren, The RCP greenhouse gas concentrations and their extensions from 1765 to 2300. Clim. Change 109, 213-241 (2011). doi:10.1007/s10584-011-0156-Z

28. J. Guiot, F. Torre, D. Jolly, O. Peyron, J. J. Boreux, R. Cheddadi, Inverse vegetation modeling by Monte Carlo sampling to reconstruct paleoclimate under changed precipitation seasonality and $\mathrm{CO}_{2}$ conditions: Application to glacial climate in Mediterranean region. Ecol. Modell. 127, 119-140 (2000). doi:10.1016/S0304$\underline{3800(99) 00219-7}$ 